\title{
Curcumin sensitizes quiescent leukemic cells to antimitotic drug 5-fluorouracil by inducing proliferative responses in them
}

\author{
Anagha Gardane, Mariyah Poonawala, Anuradha Vaidya \\ Symbiosis School of Biomedical Sciences, Symbiosis International University, Lavale, Pune 412115, India.
}

Correspondence to: Dr. Anuradha Vaidya, Deputy Director, Symbiosis School of Biomedical Sciences, Symbiosis International University, Symbiosis Knowledge Village, Gram: Lavale, Taluka: Mulshi, District: Pune 412115, India. E-mail: dydirector@ssbs.edu.in

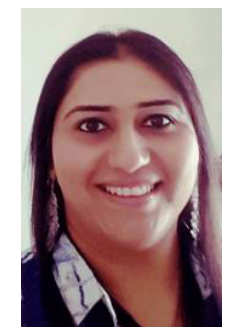

Dr. Anuradha Vaidya is the Deputy Director of Symbiosis School of Biomedical Sciences (SSBS), Symbiosis International University (SIU), Pune. Broadly, her area of research is microenvironment-mediated regulation of stem cell fate. Areas of expertise include Stem Cell Biology, Niche Biology, Experimental Hematology, Cancer Biology and Signal Transduction.

\begin{abstract}
Long-term quiescence or dormancy is a fundamental feature of cancer stem cells (CSCs) that are genetically identical to the malignant clone but constitute the only cells with tumor propagation potential within the overall tumor population. These quiescent cells show significant resistance to radiation and antiproliferative chemotherapy due to distinctive properties that seem to be related to their stem cell-like character. Hence, successful anticancer therapy must consist of approaches that can target not only the differentiated cancer cells, but also the CSCs. Using serum-starved KGla cell line as an experimental model system of quiescent leukemic cells (QLCs), the present study demonstrates that QLCs exposed to low concentrations of curcumin show high proliferative potential. Furthermore, when subjected to a combination therapy consisting of low concentrations of curcumin and 5-fluorouracil (5-FU), the QLCs displayed a high kill with an increase in the levels of nitric oxide (NO) and reactive oxygen species. These results were further consolidated with the observation of high caspase-3 activity in cells subjected to the combination therapy. This may suggest that low concentrations of curcumin stimulate the QLCs to become mitotically active, thereby sensitizing them to killing by the antimitotic drug, 5-FU.
\end{abstract}

Key words: Acute myeloid leukemia; KGla cell line; curcumin; 5-fluorouracil; quiescent leukemic cells

\section{INTRODUCTION}

Acute myeloid leukemia (AML) is a heterogeneous clonal disorder of hematopoietic progenitor cells that is characterized by a blockage of differentiation and an accumulation of immature non-functional myeloid cells in the blood. ${ }^{[1]}$ It is the most common malignant myeloid disorder among children and adults. ${ }^{[2]}$ The mainstream approach for AML treatment is chemotherapy, radiation, or surgery. ${ }^{[1,3]}$ However, the association between conventional therapy and severe toxicity followed by a tendency to relapse or metastasize cannot be ignored. ${ }^{[3,4]}$ In many cases resistance to therapy develops, leaving AML patients with no alternative but to undergo bone marrow transplantation (BMT) for a disease-free survival. ${ }^{[2,4]}$

\begin{tabular}{|l|l|}
\hline \multicolumn{2}{|c|}{ Access this article online } \\
\hline Quick Response Code: & Website: \\
\hline & http://www.jcmtjournal.com \\
\cline { 2 - 2 } & \\
\hline
\end{tabular}

According to cancer stem cell (CSC) theory, CSCs are responsible not only for tumor initiation, development, and metastasis but also for therapeutic resistance. ${ }^{[3,5-7]}$ These cells were first identified by Bonnet and $\operatorname{Dick}^{[8]}$ in AML. Following their findings many other groups have identified these cells in various solid tumors, such as brain, breast, pancreas, and prostate. ${ }^{[9-12]}$ Standard chemotherapy and radiotherapy target only the active tumor cells. Quiescent CSCs evade therapy and remain unharmed, a major concern for the development of insensitivity towards therapy leading to relapse associated with leukemia. ${ }^{[3,5,7]}$ Furthermore, the release of inflammatory

This is an open access article distributed under the terms of the Creative Commons Attribution-NonCommercial-ShareAlike 3.0 License, which allows others to remix, tweak, and build upon the work non-commercially, as long as the author is credited and the new creations are licensed under the identical terms.

For reprints contact: service@oaepublish.com

How to cite this article: Gardane A, Poonawala M, Vaidya A. Curcumin sensitizes quiescent leukemic cells to anti-mitotic drug 5 -fluorouracil by inducing proliferative responses in them. $\mathrm{J}$ Cancer Metasta Treat 2016;2:245-52.

Received: 24-02-2016; Accepted: 27-04-2016. 
cytokines -- particularly interleukin (IL)-6, IL-8 and IL-1 -- as a consequence of induced cancer cell death has been shown to stimulate replication of $\mathrm{CSCs},{ }^{[13,14]}$ and also affect at multiple sites along CSC pathways such as Wnt, Notch, Hedgehog, and focal adhesion kinase (FAK). ${ }^{[7,12,13]}$ CSCs that are generated as a result of chemotherapyinduced tumor cell death that stimulates the release of inflammatory cytokines have been reported to be more refractory to therapy. ${ }^{[13,15,16]}$ This suggests that, for therapy to be consistently effective, it must eliminate both CSCs and non-stem cell cancer cells.

Currently research is being done to harness the medicinal properties of natural compounds for treating leukemia. ${ }^{[17,18]}$ Natural compounds are cheap, are easily available, and do not cause any adverse effects. ${ }^{[17,18]}$ Curcumin is a well-known dietary polypheno ${ }^{[19-21]}$ and is an active ingredient of turmeric that possesses antioxidant and antiinflammatory activities. ${ }^{[19,21]}$ Its safety and tolerability has been well-established by numerous clinical studies. ${ }^{[19,21]}$ It has been shown that curcumin has significant cytotoxic and apoptotic effects on the promyelocytic cell line, HL60 , suggesting that it may have a potential therapeutic role for human leukemia. ${ }^{[22-25]}$ A study conducted by Fong et al. ${ }^{[2]]}$ showed that curcumin inhibited the side population (SP) phenotype of the rat C6 glioma cell line, demonstrating for the first time in vivo that curcumin has anticarcinogenic and antimetastatic activity in the brain. Another study demonstrated that curcumin is able to target breast stem/progenitor cells, as evidenced by suppressed mammosphere formation along serial passage and by a decrease in the percent of aldehyde dehydrogenase (ALDH)-positive cells. ${ }^{[27-29]}$

To summarize, several cell and animal studies have demonstrated and corroborated the apoptotic activity and anticancer effect of curcumin in different types of cancers, ${ }^{[30-34]}$ and recent research has shown that curcumin can also target CSCs. ${ }^{[35]}$ In the present work we demonstrate that curcumin, at low concentrations, induces proliferative responses in QLCs, thereby sensitizing them to the antimitotic drug, 5-fluorouracil (5-FU).

\section{METHODS}

\section{Reagents}

Curcumin, Fetal Bovine Serum (FBS), Griess Reagent, Dichloro-dihydro-fluorescein diacetate (DCFH-DA), Propidium Iodide (PI), 3-(4, 5-Dimethylthiazol-2-yl)-2, 5-Diphenyltetrazolium Bromide (MTT), 5- Fluorouracil (5-FU), Dimethyl Sulfoxide (DMSO), RNase-A were purchased from Sigma-Aldrich, USA; Iscove's Modified Dulbecco's Media (IMDM), L-Glutamine, Antibiotic Solution (Penicillin + Streptomycin), Trypan Blue Dye, Phosphate Buffer Saline (PBS) were purchased from Himedia, India; Caspase-3 Colorimetric Assay Kit was purchased from RayBiotech.

\section{Cell culture}

KG1a cell line was procured from National Centre for Cell Science (NCCS), Pune, India and was maintained under standard conditions as per the ATCC guidelines. KG1a is a variant sub-line of $\mathrm{KG} 1$ that is morphologically and functionally less mature than KG1. It does not respond to colony-stimulating factors in soft agar assays. Cells were starved in low serum $(0.5 \% \mathrm{FBS})$ medium overnight to prepare Quiescent Leukemic Cells (QLCs) from them. ${ }^{[36]}$

QLCs were subjected to various treatments as follows:

1. Treatment with only curcumin (CU): QLCs were treated with various concentrations of curcumin ranging from $10 \mu \mathrm{g}$ to $100 \mu \mathrm{g} / \mathrm{mL}$ in growth medium (IMDM supplemented with $20 \% \mathrm{FBS}$ ) for $48 \mathrm{~h}$.

2. Treatment with only 5-fluorouracil (5-FU): QLCs were exposed to varying concentrations of 5-FU (6$100 \mu \mathrm{g} / \mathrm{mL}$ ) in growth medium for $24 \mathrm{~h}$.

3. Combinatorial treatment: QLCs subjected to curcumin treatment $(10-100 \mu \mathrm{g} / \mathrm{mL})$ for a period $48 \mathrm{~h}$ (step 1) were harvested and resuspended in fresh growth medium containing $6 \mu \mathrm{g} / \mathrm{mL}$ of 5 -FU. The cells were further incubated for a period of $24 \mathrm{~h}$ after which they were subjected to various biochemical assays as described below.

\section{3-(4,5-Dimethylthiazol-2-yl)-2,}

\section{5-Diphenyltetrazolium Bromide (MTT) assay}

QLCs exposed to various treatments were subjected to a standard MTT assay as discussed before, and the percent proliferation was determined. ${ }^{[36]}$

\section{Growth curve experiment}

Growth curve experiment was performed to determine the doubling time. QLCs were treated with $10 \mu \mathrm{g} / \mathrm{mL}$ curcumin, and viable cell counts were taken at specified time intervals using trypan blue dye exclusion method.

\section{Flow cytometric analysis of cell cycle}

Cell cycle analysis using propidium iodide (PI) staining was performed to distinguish the cells in various stages of the cell cycle. Briefly, the QLCs exposed to various treatments were stained with PI, after which analysis of the cell cycle was performed using BD FACSCalibur ${ }^{\mathrm{TM}}$ (BD Biosciences, USA).

\section{Nitric oxide (NO) assay}

Nitric oxide assay was performed using modified Griess reagent for the colorimetric detection of NO production by QLCs subjected to curcumin and/or antimitotic drug treatment(s) at $540 \mathrm{~nm}$ using BioTek ${ }^{\mathrm{TM}}$ Eon $^{\mathrm{TM}}$ Microplate Spectrophotometer (USA).

\section{2', 7'-dichlorofluorescein diacetate (DCFDA) assay}

QLCs exposed to curcumin and/or antimitotic drug treatment(s) were checked for the generation of Reactive 
Oxygen Species (ROS) by DCFDA assay. QLCs were incubated with $10 \mu \mathrm{M}$ DCFDA for $30 \mathrm{~min}$ at $37^{\circ} \mathrm{C}$. After incubation, 2', 7'-dichlorofluorescein (DCF) was measured at $495-529 \mathrm{~nm}$ by using a fluorometer (Fluoroskan Ascent, Thermo Fisher Scientific, USA).

\section{Apoptotic assay}

This assay was performed as per manufacturer's instructions (RayBiotech) to estimate the caspase-3 activity of the QLCs. The intensity of the color was measured at 400/405 $\mathrm{nm}$ by using a spectrophotometer reader (BioTek ${ }^{\mathrm{TM}}$ Eon $^{\mathrm{TM}}$ Microplate, USA).

\section{Statistical analyses}

The data were analyzed by One-way Repeated Measure Analysis of Variance (One-Way RM ANOVA). The Standard Error of Mean (S.E.M.) values were used for plotting the error bar graphs, using the SigmaPlot software (version 13.0). Level of significance was denoted as follows: $* P \leq 0.05, * * P \leq 0.01$ and $* * * P \leq 0.001$.

\section{RESULTS}

\section{Low concentrations of curcumin induce proliferation of quiescent leukemic cells}

It has been shown that curcumin inhibits cell proliferation, causes cell cycle arrest, and initiates apoptosis in several human cancer cell lines. ${ }^{[37,38]}$ We first wanted to determine the concentration(s) of curcumin that would be most effective against the QLCs. Hence we cultured the serumstarved KG1a cells for $48 \mathrm{~h}$ with various concentrations $(10-100 \mu \mathrm{g} / \mathrm{mL})$ of curcumin. We were expecting to see a dose-dependent inhibitory effect of curcumin on the QLCs. Intrestingly, however, we observed that low concentrations of curcumin $(10 \mu \mathrm{g} / \mathrm{mL}$ and $20 \mu \mathrm{g} / \mathrm{mL})$ stimulated the cells to undergo proliferation, whereas at all other concentrations of curcumin ( $30 \mu \mathrm{g} / \mathrm{mL}$ to $100 \mu \mathrm{g} / \mathrm{mL}$ ) imparted inhibitory effects [Figure 1]. Our proposition is that since KG1a cells are known to contain leukemia-like stem cells, ${ }^{[16]}$ low concentrations of curcumin could have induced the leukemia-like stem cells to proliferate.

\section{Curcumin results in an increased cell yield by reducing the doubling time of QLCs}

Since low concentrations $(10 \mu \mathrm{g} / \mathrm{mL}$ and $20 \mu \mathrm{g} / \mathrm{mL})$ of curcumin led to proliferation of the QLCs, we next wanted to know whether treatment with curcumin would alter the cell cycle kinetics. Serum-starved KG1a cells were treated with $10 \mu \mathrm{g} / \mathrm{mL}$ of curcumin, and viable cell counts using trypan blue dye exclusion method were taken at every $24 \mathrm{~h}$ interval for a period of 6 days. As seen in Table 1, it was observed that till day 4 , the doubling time of QLCs treated with curcumin was reduced to almost half that of the untreated cells. The minimum doubling time of $6.14 \mathrm{~h}$ was observed on the second day. It is also important to note that the doubling time of curcumintreated cells was lower than that of untreated cells for all 6 days [Figure 2].
Table 1: Doubling time of untreated versus treated QLCs

\begin{tabular}{lccc}
\hline & Time interval & \multicolumn{2}{c}{ Doubling time in hours } \\
\cline { 3 - 4 } in hours & $\begin{array}{c}\text { Untreated } \\
\text { QLCs }\end{array}$ & $\begin{array}{c}\text { QLCs + curcumin } \\
(\mathbf{1 0} \boldsymbol{\mu g} / \mathbf{m L})\end{array}$ \\
\hline 1 & $0-24$ & 23.99 & 11.99 \\
2 & $24-48$ & 11.99 & 6.14 \\
3 & $48-72$ & 29.74 & 13.97 \\
4 & $72-96$ & 36 & 18.15 \\
5 & $96-120$ & 44.8 & 28.2 \\
6 & $120-144$ & 35.3 & 20.5 \\
\hline
\end{tabular}

QLCs: quiescent leukemic cells

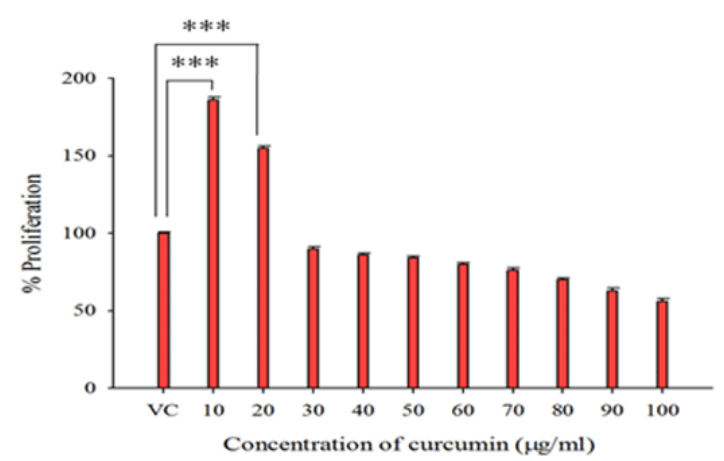

Figure 1: QLCs undergo proliferation in response to low concentrations of curcumin: Serum-starved KG1a cells were treated with varying concentrations of curcumin $(10-100 \mu \mathrm{g} / \mathrm{mL})$ for $48 \mathrm{~h}$ and were subjected to MTT assay. Treatment with low concentrations $(10 \mu \mathrm{g} / \mathrm{mL}$ and $20 \mu \mathrm{g} / \mathrm{mL})$ of curcumin led to proliferation of QLC cells as compared to the vehicle control (VC) cells. The data represent mean \pm S.E.M. of three independent experiments $\left({ }^{* *} P \leq 0.001\right)$

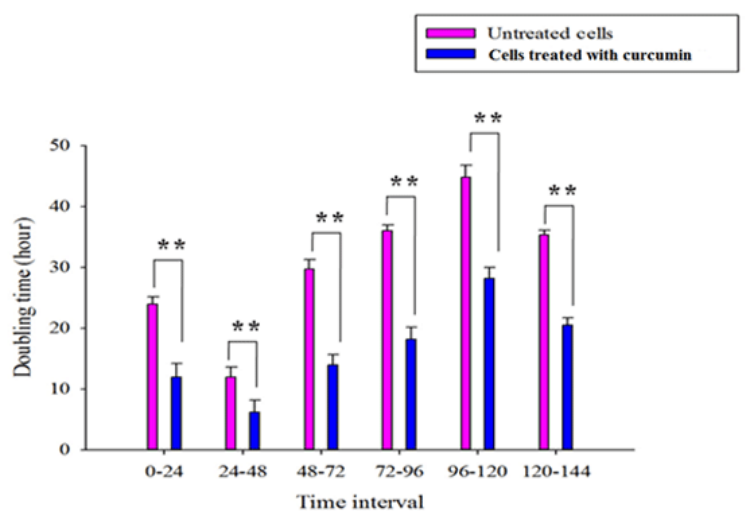

Figure 2: Treatment with curcumin reduces the doubling time of QLCs: QLCs were treated with $10 \mu \mathrm{g} / \mathrm{mL}$ of curcumin. Viable cell count was taken at an interval of $24 \mathrm{~h}$ for 6 days. Although minimum doubling time (6.14 h) was observed at Day $2(24-48 \mathrm{~h})$, the overall doubling time of curcumintreated cells was always lower than the doubling time of vehicle control $(\mathrm{VC})$. The data represent mean \pm S.E.M of three independent experiments $\left({ }^{* *} P \leq 0.01\right)$

5-Fluorouracil inhibits the proliferation of QLCs in a dose-dependent manner

The presence of leukemic stem cells (LSCs), also known as cancer stem cells (CSCs), is a major problem in the treatment of leukemia. The LSCs are refractory 

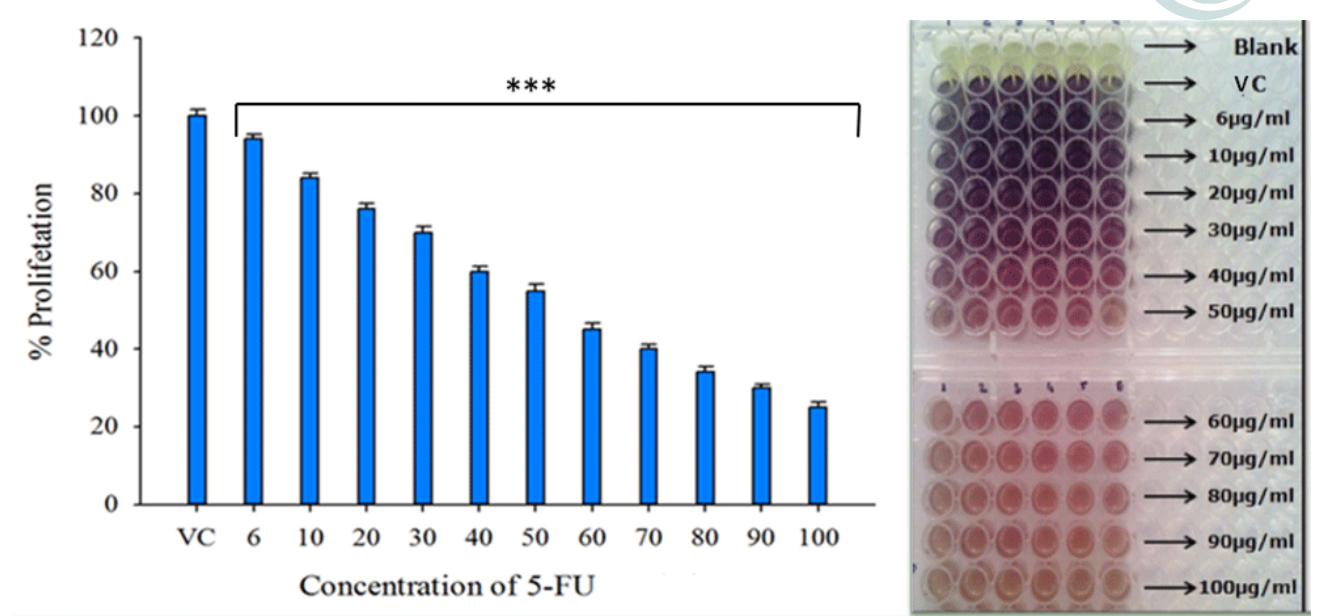

Figure 3: 5-Fluorouracil imparts its cytotoxic effect on quiescent KG1a cells in a dose-dependent manner: Serum-starved KG1a cells were incubated with different concentrations of 5-FU $(6 \mu \mathrm{g}, 10 \mu \mathrm{g}$ to $100 \mu \mathrm{g} / \mathrm{mL})$ for $24 \mathrm{~h}$ and were subsequently subjected to MTT assay. As seen in the graph, QLCs displayed a dose-dependent response to increasing concentrations of 5 -FU. The data represent mean \pm S.E.M. of three independent experiments ( ${ }^{* * *} P \leq 0.001$ )
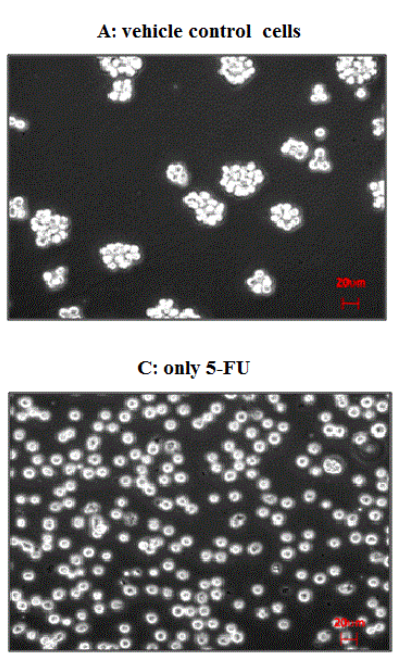
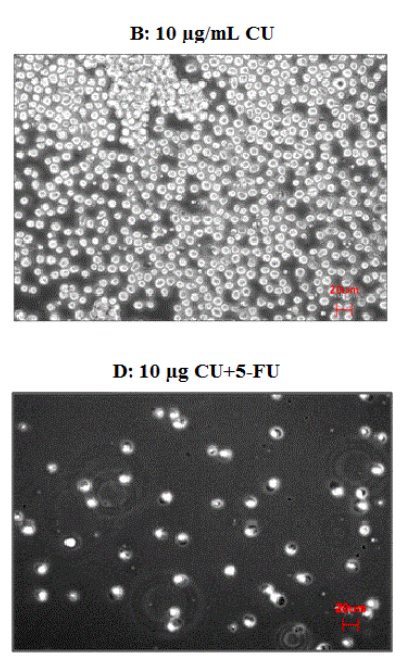

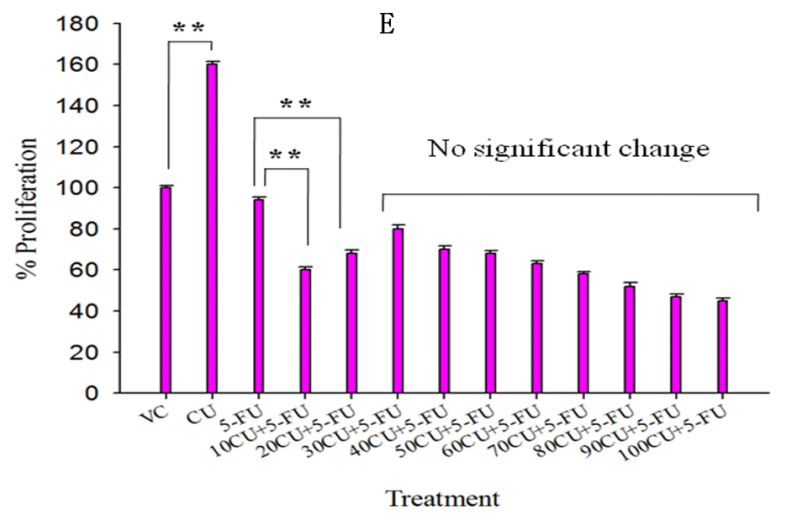

Figure 4: Treatment with low concentrations of curcumin sensitizes the QLCs to the antimitotic agent, 5-FU: Serum-starved KG1a cells were incubated with different concentrations of curcumin $(10-100 \mu \mathrm{g} / \mathrm{mL})$ for $48 \mathrm{~h}$. After $48 \mathrm{~h}$, the QLCs were further incubated with 5 -FU $(6 \mu \mathrm{g} / \mathrm{mL})$ for another $24 \mathrm{~h}$. When the cells were subjected to MTT assay (E), it was observed that the percent proliferation of QLCs exposed to the combination treatment (10CU + 5-FU, 20CU $+5-\mathrm{FU}$ ) was lower than for the cells treated with only 5-FU. The data represent mean \pm S.E.M. of three independed expriments (** $P \leq 0.01)$. (A-D) They represent phase contrast images using a $20 \times$ objective of an inverted microscope (Carl Zeiss, $200 \times$ magnifications) of QLCs exposed to curcumin and/or 5-FU. (A) Vehicle control QLCs growing in clumps; (B) QLCs exposed to $10 \mu \mathrm{g} / \mathrm{mL}$ curcumin, showing maximum proliferation; (C) QLCs exposed to only 5-FU; (D) QLCs exposed to $10 \mu \mathrm{g} / \mathrm{mL}$ curcumin and 5-FU, showing fewer cells, indicating that the QLCs have been more efficiently killed by 5-FU; (E) graphical representation of QLCs subjected to MTT assay

to treatment, and their presence is associated with relapses. ${ }^{[13,15,16]}$ In 2008, Vaidya et al. ${ }^{[36]}$ showed that inhibition of p38 mitogen-associated protein kinase (MAPK) sensitizes the QLCs to antimitotic agents 5-FU and cytosine arabinoside (Ara-C). Since the treatment of QLCs with low concentrations of curcumin was pushing the cells into proliferation, we conjectured that this proliferative response could be translated to increase the sensitivity of the leukemic cells to antimitotic agents. Hence, we first reconfirmed whether serum-starved KG1a cells were a good model system to study the effects of antimitotic drugs. We exposed the quiescent KG1a cells to different concentrations of 5-FU and subjected them to MTT assay. As shown in Figure 3, 5-FU induced dosedependent killing of the quiescent KG1a cells, thereby validating it as a good model system for testing the efficacy of antimitotic drugs.
Quiescent leukemic cells prepared from KG1a get sensitized to low levels of 5-FU when treated with low concentrations of curcumin

Based on our previous studies, ${ }^{[36]}$ we wanted to examine whether the proliferative response induced by low concentrations of curcumin treatment would make the quiescent leukemic cells more susceptible to the mitotic inhibitor 5-FU. KG1a cells that were made quiescent by serum deprivation were first treated with low concentrations of curcumin $(10 \mu \mathrm{g} / \mathrm{mL}$ and $20 \mu \mathrm{g} / \mathrm{mL})$ and then exposed to $6 \mu \mathrm{g} / \mathrm{mL}$ (lowest concentration) of 5-FU. ${ }^{[36]}$ MTT assay was then carried out to assess the percent proliferation of the cells. It was observed [Figure 4E] that QLCs that were treated with a combination of 5-FU and low concentrations of curcumin were more effectively killed (low percent proliferation: $60 \%$ and $65 \%$ for $10 \mu \mathrm{g} / \mathrm{mL}$ and $20 \mu \mathrm{g} / \mathrm{mL}$, respectively) as compared to 

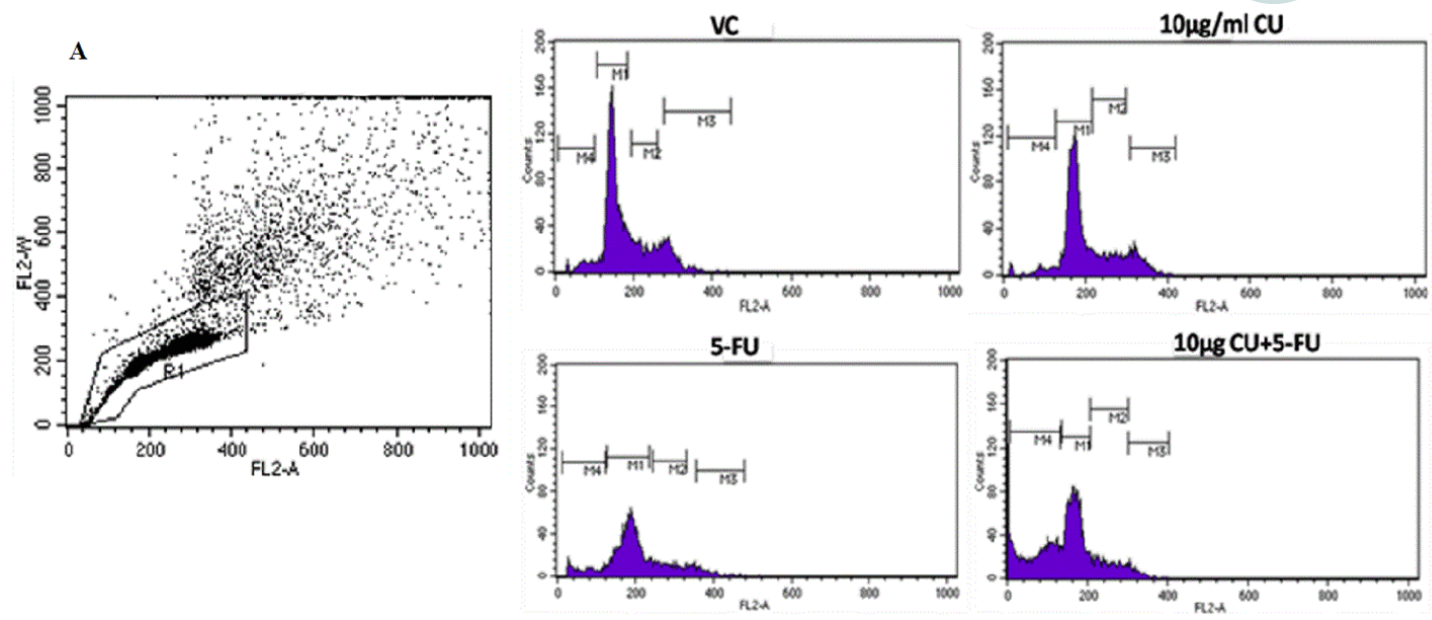

B

\begin{tabular}{|c|c|c|c|c|c|}
\hline \multirow[b]{2}{*}{ Marker } & \multirow{2}{*}{$\begin{array}{l}\text { Stages of } \\
\text { cell cyde }\end{array}$} & \multicolumn{4}{|c|}{ Pereent Gated } \\
\hline & & vC & $10 \mathrm{pg} / \mathrm{mlCV}$ & 5-FU & $\begin{array}{c}10 \mu / \mathrm{mlCU} \\
+ \\
5-\mathrm{FU}\end{array}$ \\
\hline M1 & G0/G1 & 85.95 & 40.44 & 74.29 & 38.68 \\
\hline M2 & s & 2.37 & 29.76 & 6.77 & 30.75 \\
\hline M3 & G2/M & 1.15 & 13.01 & 2.81 & 15.62 \\
\hline M4 & Dead cells & 3.71 & 288 & 9.87 & 30.58 \\
\hline
\end{tabular}

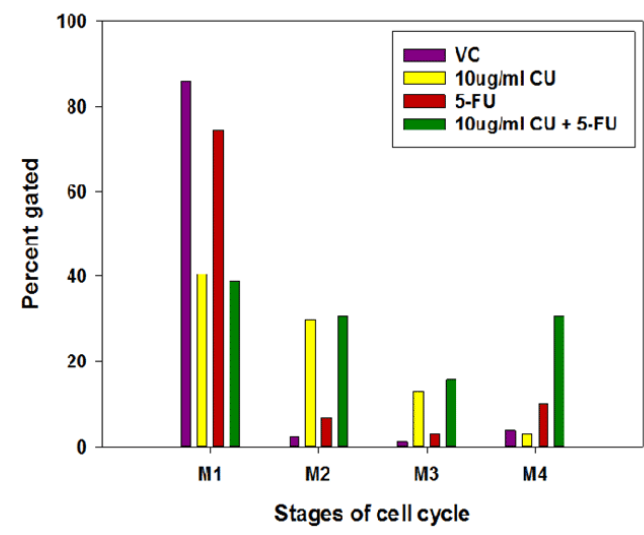

Figure 5: Cell cycle analysis showing that curcumin causes greater migration of QLCs from the $\mathrm{G}_{0} / \mathrm{G}_{1}$ phase to other stages of the cell cycle: QLCs were treated with curcumin $(10 \mu \mathrm{g} / \mathrm{mL})$ for $48 \mathrm{~h}$. After $48 \mathrm{~h}$ the quiescent cells were incubated with 5 -FU $(6 \mu \mathrm{g} / \mathrm{mL})$ for another $24 \mathrm{~h}$ and then subjected to $\mathrm{P}$ staining. The stained cells were acquired and analyzed using BD FACSCalibur ${ }^{\mathrm{TM}}$. As compared to the vehicle control (VC), a much higher percentage of cells treated with curcumin were pushed into the $S$ and $G_{2} / M$ phase. More importantly, the QLCs that were exposed to curcumin were more effectively killed by 5-FU than cells that were not. (A) Side scatter plot of untreated vehicle control cells (QLCs), where R1 is the gated population of QLCs that is positive for $\mathrm{PI}$. The histograms demonstrate a distinct pattern of the different phases of the cell cycle marked as $M 1\left(G_{1} / G_{0}\right.$ phase), $M 2$ (S-phase), $M 3\left(G_{2} / M\right.$ phase $)$ and M4 (Dead cells) of untreated QLCs (VC) and of QLCs subjected to curcumin and/or 5-FU treatments; (B) a tabular and graphical representation of Figure $5 A$, depicting the percentage of gated QLCs in each stage of the cell cycle in response to treatment with cucrumin and/or 5-FU

the cells that were treated with 5-FU alone (higher percent proliferation: $90 \%$ ). Figure 4 (A-D) represents phase contrast images of QLCs that were untreated [Figure 4A] or exposed to only curcumin [Figure 4B], only 5-FU [Figure 4C] and both curcumin and 5-FU [Figure 4D]. It is clearly seen that QLCs that were exposed to only curcumin underwent high proliferation and were more susceptible to the antimitotic effects of 5-FU.

Curcumin pushes the QLCs into the S phase of the cell cycle which sensitizes them to killing by the antimitotic drug 5-FU

The antimitotic drug, 5-fluorouracil (5-FU) selectively kills the cells in the S-phase of the cell-cycle, leaving the quiescent leukemic cells (QLCs) unharmed. ${ }^{[3,39]}$ Hence, our next step was to check whether the induction of proliferative responses in presence of low concentration(s) of curcumin was pushing the QLCs into the S phase of the cell cycle.

In this set of experiments, serum-starved KG1a cells were treated with curcumin and/or 5-FU, after which they were taken for propidium iodide (PI) staining. Figure 5B shows that, as compared to the vehicle control (VC) cells (M2 = $2.37 \%$ ), a greater number of curcumin-treated cells (M2 $=29.76 \%$ ) migrated from $\mathrm{G}_{0} / \mathrm{G}_{1}$ phase towards $\mathrm{S}$ phase of cell cycle. It was also observed that as a consequence, fewer number of curcumin-treated cells (M1 $=40.44 \%)$ were present in $\mathrm{G}_{0} / \mathrm{G}_{1}$ phase than in the untreated cells (M1 $=85.95 \%)$. In QLCs that were exposed to combination treatment (curcumin $+5-\mathrm{FU}$ ), a profile similar to curcumin-only cells was observed in M1, M2, and M3 stages. However, a striking difference was seen at the M4 stage between the cells that were subjected to combination treatment (M4 $=30.58 \%)$ (green bar at M4 of Figure 5B) and those that were treated with 5 -FU only (M4 $=9.87 \%$ ) (red bar of at M4 Figure 5B). The difference indicates that the proliferative responses induced by curcumin sensitized the QLCs to killing by the antimitotic drug 5-FU.

\section{QLCs exposed to combination treatment show higher caspase-3 activity}

The flow cytometric analysis of the cell cycle effectively demonstrated that the exposure to curcumin was helpful in improving the outcome of antimitotic drug therapy [Figure 5B]. However, we wanted to confirm whether the 


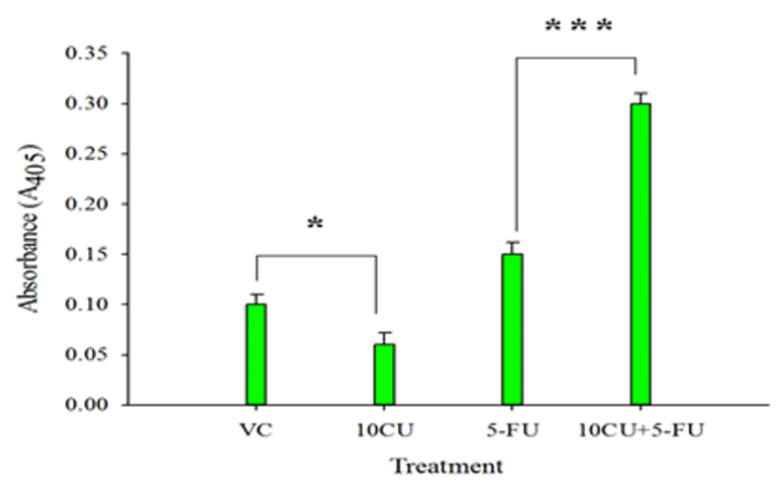

Figure 6: Combination therapy promotes higher caspase-3 activity in quiescent leukemic cells. QLCs were treated as represented in the graph. The treated cells were harvested and subjected to caspase- 3 assay. Intensity of the color was measured at $400 / 405 \mathrm{~nm}$ by using microplate spectrophotometer. In the graph, VC represents vehicle control; $10 \mathrm{CU}$ represents the cells treated with curcumin only $(10 \mu \mathrm{g} / \mathrm{mL}) ; 5-F U$ represents cells treated with 5 -FU only $(6 \mu \mathrm{g} / \mathrm{mL})$, and $10 \mathrm{CU}+5$-FU represents combination treatment of $10 \mu \mathrm{g} / \mathrm{mL}$ of curcumin and $6 \mu \mathrm{g} / \mathrm{mL}$ of $5-F U$. Serumstarved KG1a cells treated with $10 \mu \mathrm{g} / \mathrm{mL}$ of curcumin induce minimum caspase-3 activity as compared to VC. Cells treated with a combination of $10 \mu \mathrm{g} / \mathrm{mL}$ of curcumin and $6 \mu \mathrm{g} / \mathrm{mL}$ of $5-\mathrm{FU}$ induces maximum caspase-3 activity as compared to the cells exposed to only 5-FU. The data represent mean \pm S.E.M of three independent experiments $\left({ }^{*} P \leq 0.05\right.$, $\left.{ }^{* *} P \leq 0.001\right)$

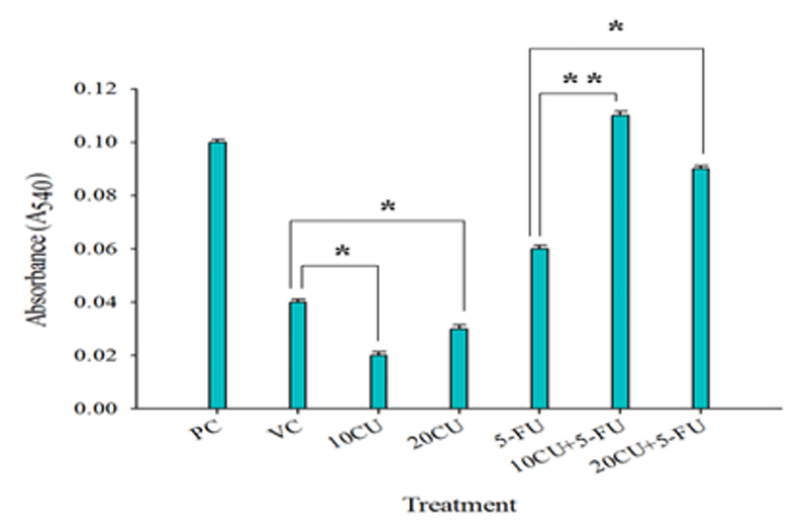

Figure 7: Combination treatment with low curcumin concentrations and 5-FU leads to higher generation of NO in quiescent KG1a cells: QLCs were subjected to various treatments as shown in the graph. After treatment, the cells were spun, supernatant was collected into fresh plates and to the supernatant was added an equal volume of Griess reagent. The plate was incubated for $15 \mathrm{~min}$ in dark at room temperature (RT) and the intensity of color was measured at $540 \mathrm{~nm}$ using microplate spectrophotometer. PC represents positive control, that is sodium nitrite solution $(50 \mu \mathrm{m})$. VC represents vehicle control; $10 \mathrm{CU}$ and $20 \mathrm{CU}$ represent the concentrations of curcumin used, that is cells treated with only $10 \mu \mathrm{g} / \mathrm{mL}$ and $20 \mu \mathrm{g} / \mathrm{mL}$ respectively; 5 -FU represents cells treated with only $6 \mu \mathrm{g} / \mathrm{mL}$ of $5-\mathrm{FU}$; $10 \mathrm{CU}+5-\mathrm{FU}$, and $20 \mathrm{CU}+5-\mathrm{FU}$ represents cells treated with combinatorial treatment of curcumin $(10 \mu \mathrm{g} / \mathrm{mL}$ or $20 \mu \mathrm{g} / \mathrm{mL})$ and $5-\mathrm{FU}(6 \mu \mathrm{g} / \mathrm{mL})$. Serumstarved KG1a cells treated with $10 \mu \mathrm{g} / \mathrm{mL}$ and $20 \mu \mathrm{g} / \mathrm{mL}$ of curcumin generated minimum amount of nitrites as compared to VC, whereas cells treated with a combination of $10 \mu \mathrm{g} / \mathrm{mL}$ or $20 \mu \mathrm{g} / \mathrm{mL}$ of curcumin and $6 \mu \mathrm{g} / \mathrm{mL}$ of 5-FU, respectively, showed maximum levels of nitrite as compared to the cells treated with only $5-\mathrm{FU}$. The data represents mean \pm S.E.M of three independed experiments ( ${ }^{*} P \leq 0.05,{ }^{* *} P \leq 0.01$ )

QLCs that were being targeted by 5-FU were undergoing apoptosis. To check the apoptotic profile of QLCs treated with both curcumin and 5-FU, we performed caspase-3 assay as per manufacturer's instructions. As seen in Figure 6 , there was indeed a high caspase-3 activity in cells treated with combination therapy when compared to those treated with only 5-FU. This confirms that curcumin sensitized the QLCs to undergo apoptosis in presence of the antimitotic

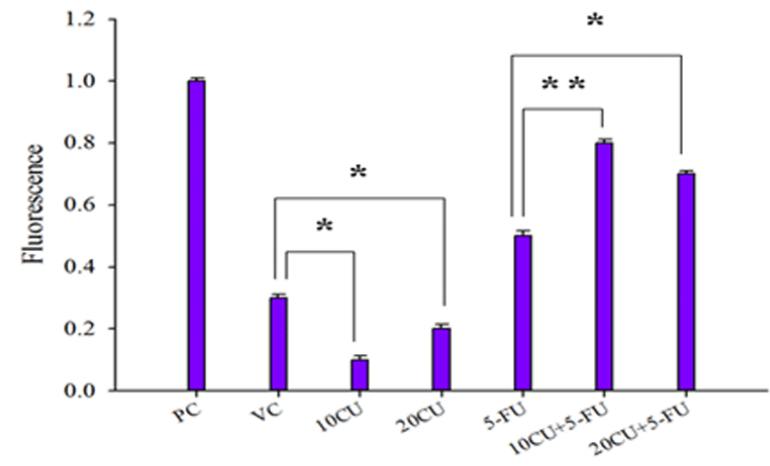

Treatment

Figure 8: QLCs subjected to combination treatment generate higher levels of ROS: Quiescent cells generated from KG1a cells were incubated with low concentrations of curcumin only $(10 \mu \mathrm{g} / \mathrm{mL}$ and $20 \mu \mathrm{g} / \mathrm{mL}), 5-\mathrm{FU}$ only $(6 \mu \mathrm{g} / \mathrm{mL})$ and a combination of curcumin and 5-FU, as shown in the graph. The treated cells were collected and spun, and the cell pellet was incubated with $100 \mu \mathrm{L}$ of DCFDA $(10 \mu \mathrm{m})$ for $30 \mathrm{~min}$ at $37^{\circ} \mathrm{C}$. After incubation the cells were centrifuged, and the pellet was resuspended in $1 \times$ PBS. The fluorescence was measured at $495-529 \mathrm{~nm}$. In the graph, $\mathrm{PC}$ represents positive control that is hydrogen peroxide $(50 \mu \mathrm{m})$, VC represents vehicle control; $10 \mathrm{CU}$ and $20 \mathrm{CU}$ are cell samples treated with curcumin only ( $10 \mu \mathrm{g} / \mathrm{mL}$ and $20 \mu \mathrm{g} / \mathrm{mL}$, respectively), 5 -FU represents 5 -FU only $(6 \mu \mathrm{g} / \mathrm{mL})$ treated cells, and $10 \mathrm{CU}+5-\mathrm{FU}, 20 \mathrm{CU}+5-\mathrm{FU}$ represents combination treatment of curcumin $(10 \mu \mathrm{g} / \mathrm{mL}$ or $20 \mu \mathrm{g} / \mathrm{mL})$ and $5-\mathrm{FU}(6 \mu \mathrm{g} / \mathrm{mL})$, respectively. Quiescent KG1a cells treated with only $10 \mu \mathrm{g} / \mathrm{mL}$ or $20 \mu \mathrm{g} / \mathrm{mL}$ of curcumin generated minimum amount of ROS, as compared to VC. QLCs treated with a combination of $10 \mu \mathrm{g} / \mathrm{mL}$ or $20 \mu \mathrm{g} / \mathrm{mL}$ curcumin, respectively, and $6 \mu \mathrm{g} / \mathrm{mL}$ of $5-\mathrm{FU}$ showed maximum ROS generation as compared to the cells treated with only $5-\mathrm{FU}$. The data represent mean \pm S.E.M of three independent experiments ( $P \leq 0.05,{ }^{* *} P \leq 0.01$ )

drug 5-FU.

Low concentrations of curcumin and 5-FU together increase the levels of nitric oxide in QLCs Since low concentrations of curcumin caused the proliferation of QLCs that were sensitive to 5-FU treatment, we wanted to check whether the kill seen in QLCs was being mediated by the expression of nitric oxide (NO). NO is known to react with superoxide at a high rate $\left(\mathrm{k} \geq 6.7 \times 10^{9} \mathrm{M}^{-1} \mathrm{~s}^{-1}\right)$ to form peroxynitrite, which is far more reactive and damaging than its precursors. ${ }^{[40]}$ The downstream products of superoxide, including hydrogen peroxide and peroxynitrite, are potent oxidants that induce oxidative injury of cells, resulting in apoptosis..$^{[41,42]}$ Nitric oxide assay determines nitric oxide based on the enzymatic conversion of nitrate to nitrite by nitrate reductase ${ }^{[43,44]}$ The reaction is followed by a colorimetric detection of nitrite as an azo dye product of the Griess reaction, which absorbs light at $540 \mathrm{~nm}$. As seen in Figure 7, cells that were treated with a combination of both curcumin and 5-FU expressed higher levels of NO than cells that were treated with only curcumin or only 5 -FU.

\section{Combination treatment of quiescent KG1a cells with low concentrations of curcumin and 5-FU stimulates higher generation of reactive oxygen species}

Generally, the production of ROS by mitochondria is a consequence of the blockade of the electron transfer chain. It has been well documented that $\mathrm{NO}$ can inhibit the activity 
of several enzymes of the mitochondrial respiratory chain including complex I, complex II-III, and complex IV in the cells. ${ }^{\left[{ }^{[1,45,46]}\right.}$ The inhibition of mitochondrial respiration by NO may increase the electron leakage and cause the formation of endogenous ROS (mainly superoxide anion), which can be observed in submitochondrial particles. ${ }^{[46-48]}$ High levels of ROS may cause the oxidative damage of various cellular components and finally result in cell death. ${ }^{[45,46]}$ ROS is capable of causing oxidative damage to biomacromolecules, leading to lipid peroxidation, oxidation of amino acid residues (especially cysteine residues), formation of protein-protein cross-links, and DNA oxidative damage. ${ }^{[41,49]}$ Since we had seen a high expression of $\mathrm{NO}$ in cells treated with the combination of curcumin and 5-FU, we were interested in finding out whether these cells would also generate high levels of ROS. The QLCs treated with a combination of curcumin and 5-FU were subjected to DCFDA assay. It was observed [Figure 8] that combination treatment [curcumin $(10 \mu \mathrm{g} / \mathrm{mL}$ and $20 \mu \mathrm{g} / \mathrm{mL})+5$-FU $(6 \mu \mathrm{g} / \mathrm{mL})]$ led to an increase in the level of ROS generation $(10 \mu \mathrm{g} / \mathrm{mL}=80 \%, 20 \mu \mathrm{g} / \mathrm{mL}=$ $60 \%$ ), as compared to that generated by only 5 -FU treated cells $(40 \%)$.

\section{DISCUSSION}

AML is a hematological malignancy that results from transformation of multipotent hematopoietic progenitors and leads to accumulation of immature myeloid cells in the bone marrow. Many studies have shown that curcumin demonstrates antiproliferative, antioxidative, cytotoxic, pro-oxidant, and antitumor activity in many human cell lines, ${ }^{[1,19,21]}$ including $\mathrm{T}$ and $\mathrm{B}$ leukemia, in a dosedependent manner. ${ }^{[50,51]}$ Although it has been reported that curcumin induces apoptosis in human leukemia HL-60 cells, ${ }^{[24]}$ the exact pathway that leads to apoptosis of the HL60 cells remains unclear. Another study has demonstrated that ROS is involved in the apoptosis induced by curcumin in HL-60 cells. ${ }^{[25]}$ Additionally, it has been shown that curcumin may inhibit proliferation and induce apoptosis of leukemic cells by arresting them in various phases of the cell cycle. ${ }^{[13,14]}$ It has also been suggested that curcumin may induce apoptosis in tumor cells by a mitochondriadependent mechanism, suggesting that curcumin can activate cytochrome c caspase- $3 .[37,38,45,46,48]$

In the last few years, progressive studies have underscored the importance of a combination approach in the development of effective therapies against leukemia. It is becoming obvious that the molecular basis for most leukemias is far more complex than can be addressed by use of a single-target or single-drug approach. On one end, there are cycling cancer cells that are receptive to antimitotic drugs; on the other end, there are mitotically inactive leukemic stem cells that evade traditional anticancer therapies. As a result, it is imperative to adopt a multitarget-based drug development paradigm for the treatment of complex human diseases that work by different mechanisms of action. In the present study, we have demonstrated that low concentrations of curcumin push the quiescent leukemic cells into the cell cycle, thereby sensitizing them to the antimitotic drug 5-fluorouracil. Although the molecular mechanism(s) behind the inhibitory effect of the combination therapy on leukemic cells have yet to be explained, this approach could be exploited to selectively target leukemic stem cells that are responsible for relapse associated with leukemia, and to develop novel anticancer therapies for the treatment of leukemia. Simultaneously, this approach could also be combined with other strategies employed in the ex vivo expansion of normal hematopoietic stem/ progenitor cells.

\section{Acknowledgments}

The authors wish to thank Symbiosis Centre for Research and Innovation (SCRI) and Symbiosis School of Biomedical Sciences (SSBS), Symbiosis International University (SIU), Lavale, Pune, India for supporting the research work. Authors express gratitude to Dr. Vaijayanti P. Kale, National Centre for Cell Science (NCCS), Savitribai Phule Pune University Campus, Pune, India for providing the KG1a cell line as a kind gift.

\section{Financial support and sponsorship}

Nil.

\section{Conflicts of interest}

There are no conflicts of interest.

\section{REFERENCES}

1. A1-Jifri A. Identification of the Molecular Mechanisms Responsible for the inhibition of Homing of AML Cells Triggered by CD44 -Ligation [thesis]. KAUST Repository: King Abdullah University of Science and Technology;2011.

2. Deschler B, Lubbert M. Acute myeloid leukemia: Epidemiology and Etiology. Cancer 2006;107:2099-107.

3. Croker AK, Allan AL. Cancer stem cells: Implications for the progression and treatment of metastatic disease. J Cell $\mathrm{Mol} \mathrm{Med}$ 2008;12:374-90.

4. Grimwade D, Walker H, Hamson G. The predictive value of hierarchical cytogenetic classification older adults with acute myeloid leukemia (AML) analysis of 1065 patients entered into the United Kingdom Medical Research Council AML11 trail. Blood 2001;98:1312-20

5. Gil J, Stembalska A. Cancer stem cells: the theory and perspectives in cancer therapy. J Appl Genet 2008;49:193-9.

6. Frank NY, Schatton T. The therapeutic promise of the cancer stem cell concept. J Clin Invest 2010;120:41-50.

7. Ajani JA, Songb S, Hochsterc HS, Steinberg IB. Cancer stem cells: the promise and the potential. Semin Oncol 2015;42 Suppl 1:S3-17.

8. Bonnet D, Dick JE. Human acute myeloid leukemia is organized as a hierarchy that originates from a primitive hematopoietic cell. Nat Med 1997;3:730-7.

9. Borah A, Raveendran S,Rochani A,Maekawa T, Kumar DS. Targeting self-renewal pathways in cancer stem cells: clinical implications for cancer therapy. Oncogenesis 2015;4:e77.

10. Visdaver JE, Lindeman GJ. Cancer stem cells in solid tumours:accumulating evidence and unresolved questions. Nat Rev 
Cancer 2008;8:755-68.

11. Ailles LE, Weissman IL. Cancer stem cells in solid tumours. Curr Opin Biotechnol 2007;18:460-6.

12. Gerald JP. Cancer Stem Cells and Novel Targets for Antitumor Strategies. Current Pharmaceutical Design 2012;18:2838-49.

13. Sordillo PP, Helson L. Curcumin and cancer stem cells: curcumin has asymmetrical effects on cancer and normal stem cells. Anticancer Res 2015;35:599-614.

14. Kundu JK, Surh YJ. Emerging avenues linking inflammation and cancer. Free Radic Biol Med 2012;52:2013-37.

15. Rebucci M, Michiels C. Molecular aspects of cancer cell resistance to chemotherapy. Biochem Pharmacol 2013;85:1219-26.

16. She M, Niu X, Chen X, Li J, Zhou M, He Y, Le Y, Guo K. Resistance of leukemic stem-like cells in AML cell line KG1a to natural killer cell-mediated cytotoxicity. Cancer Lett 2012;318:173-9.

17. Sak K. Chemotherapy and dietary phytochemical agents. Chemother Res Pract 2012;2012:282570.

18. Venkatraman P. Specificity in the interaction of natural products with their target proteins- a biochemical and structural insight. Mini Rev Med Chem 2010;10:540-9.

19. Li Y, Zhang T. Targeting cancer stem cells by curcumin and clinical applications. Cancer Lett 2014;346:197-205.

20. Zhou H, Beevers CS, Huang S. Targets of curcumin. Current Drug Targets 2011;12:332-47.

21. Sarkar FH, Li Y, Wang Z, Padhye S. Lesson learned from nature for the development of novel anti-cancer agents: implication of isoflavone, curcumin, and their synthetic analogs. Curr Pharm Des 2010;16:1801-12.

22. Dikmen M, Canturk Z, Ozturk Y, Tunal Y. Investigation of the apoptotic effect of curcumin in human leukemia HL-60 cells by using flow cytometry. Cancer Biother Radiopharm 2010;25:749-55.

23. Taraphdar AK, Roy M, Bhattacharya RK. Natural products as inducers of apoptosis: Implication for cancer therapy and prevention. Current Sci 2001;80:1387-96.

24. Su CC, Lin JG, Li TM, Chung JG, Yang JS, Ip SW, Lin WC, Chen GW. Curcumin-induced apoptosis of human colon cancer colo 205 cells through the production of $\mathrm{ROS}, \mathrm{Ca} 2+$ and the activation of caspase-3. Anticancer Res 2006;26:4379-89.

25. Pae HO, Jeong SO, Jeongc GS,Kim KM, Kim HS, Kim SA, Kim YC, Kang SD, Kim BN, Chung HT. Curcumin induces proapoptotic endoplasmic reticulum stress in human leukemia HL-60 cells. Biochem Biophys Res Commun 2007;353:1040-5.

26. Fong D, Yeh A, Naftalovich R, Choi HT, Chan MM. Curcumin inhibits the side population (SP) phenotype of the rat $\mathrm{C} 6$ glioma cell line: towards targeting of cancer stem cells with phytochemicals. Cancer Lett 2010;293:65-72.

27. Kakarala M, Brenner DE, Khorkaya H, Cheng C, Tazi K, Ginestier C, Liu S, Dontu G, Wicha MS. Targeting breast stem cells with the cancer preventive compounds curcumin and piperine. Breast Cancer Res Treat 2010;122:777-85.

28. $\mathrm{Hu}$ Y,Fu L. Targeting cancer stem cells: a new therapy to cure cancer patients. Am J Cancer Res 2012;2:340-56.

29. Gulcur E. Targeting breast cancer stem cells with the curcumin nanomedicine [thesis]. University of Illinios, Chicago;2012.

30. Hatcher H, Planalp R, Cho J, Torti FM, Torti SV. Curcumin: from ancient medicine to current clinical trials. Cell Mol Life Sci 2008; 65:1631-52.

31. Link A, Balaguer F, Goel A. Cancer chemoprevention by dietary polyphenols: promising role for epigenetics. Biochem Pharmacol 2010;80:1771-92.

32. Aggarwal BB, Harikumar KB. Potential therapeutic effects of curcumin, the anti-inflammatory agent, against neurodegenerative, cardiovascular, pulmonary, metabolic, autoimmune and neoplastic diseases. Int J Biochem Cell Biol 2009;41:40-59.

33. Anand P, Kunnumakkara AB, Newman RA and Aggarwal BB. Bioavailability of curcumin: problems and promises. Molecular Pharmaceutics 2007;4:807-18.

34. Noorafshan A, Ashkani-Esfahani S. A review of therapeutic effects of curcumin. Curr Pharm Des 2013;19:2032-46.

35. Li Y, Zhang T. Targeting cancer stem cells by curcumin and clinical applications. Cancer Lett 2014;346:197-205.

36. Vaidya AA, Sharma MB, Kale VP. Suppression of p38-stress kinase sensitizes quiescent leukemic cells to anti-mitotic drugs by inducing proliferative responses in them. Cancer Biol Ther 2008;7:1232-40.

37. Weir NM, Selvendiran K, Kutala VK,Tong L, Vishwanath S,Rajaram M, Tridandapani S, Anant S, Kuppusamy P. Curcumin induces $\mathrm{G} 2 / \mathrm{M}$ arrest and apoptosis in cisplatin-resistant human ovarian cancer cells by modulating akt and p38 mAPK. Cancer Biol Ther 2007;6:178-84.

38. Pillai GR, Srivastava AS, Hassanein TI, Chauhan DP, Carrier E. Induction of apoptosis in human lung cancer cells by curcumin. Cancer Lett 2004;208:163-70.

39. Trepstra W, Pleomachen RE, Prins A, Lom K, Pouwels K, Wognum AW, Wagemaker G, Löwenberg B, Wielenga JJ. Fluorouracil selectively spares acute myeloid leukemia cells with long term growth abilities in immunodeficient mice and in culture. Blood 1996;88:1944-50

40. Burney S, Caulfield JL, Niles JC, Wishnok JC, Tannenbaum SR. The chemistry of DNA damage from nitric oxide and peroxynitrite. Mutat Res 1999;424:37-49.

41. Wei T, Chen C, Hou J, Xin W, Mori A. Nitric oxide induces oxidative stress and apoptosis in neuronal cells. Biochim Biophys Acta 2000;1498:72-9.

42. Chandra J, Samali A, Orrenius S. Triggering and modulation of apoptosis by oxidative stress. Free Radic Biol Med 2000;29:323-33.

43. Bories PN, Bories C. Nitrate determination in biological fluids by an enzymatic one-step assay with nitrate reductase. Clin Chem 1995;41:904-7.

44. Misko TP, Schilling RJ, Salvemini D, Moore WM, Currie MG A fluorometric assay for the measurement of nitrite in biological samples. Anal Biochem 1993;214:11-6.

45. Scatena R, Bottoni P, Botta G, Martorana GE, Giardina B. The role of mitochondria in pharmacotoxicology: a reevaluation of an old, newly emerging topic. Am J Physiol Cell Physiol 2007;293:C12-21.

46. Kowaltowski AJ, de Souza-Pinto NC, Castilho RF, Vercesi AE Mitochondria and reactive oxygen species. Free Radic Biol Med 2009;47:333-43.

47. Radi R, Cassina A, Hodara R, Quijano C, Castro L. Peroxynitrite reactions and formation in mitochondria. Free Radic Biol Med 2002;33:1451-64.

48. Brookes PS, Yoon Y, Robotham JL, Anders MW, Sheu SS. Calcium, ATP, and ROS: a mitochondrial love-hate triangle. Am J Physiol Cell Physiol 2004;287:C817-33.

49. Carbone DL, Doorn JA, Kiebler Z, Petersen DR. Cysteine modification by lipid peroxidation products inhibits protein disulfide isomerase. Chem Res Toxicol 2005;18:1324-31.

50. Salvioli S, Sikora E, Cooper EL, and Franceschi C. Curcumin in cell death processes: a challenge for cam of age-related pathologies. Evid Based Complement Alternat Med 2007;4:181-90.

51. Sharma RA, Strimpakos AS. Curcumin: Preventive and therapeutic properties in laboratory studies and clinical trials. Antioxid Redox Signal 2008;10:511-45. 